\title{
“TABULA RASA"' PLANNING: CREATIVE DESTRUCTION AND BUILDING A NEW URBAN IDENTITY IN TEHRAN
}

\author{
Asma MEHAN \\ Department of Architecture and Design, Politecnico di Torino, \\ Viale Pier Andrea Mattioli, 39 - 10125 Torino (TO) \\ E-mail:asma.mehan@polito.it
}

Received 08 July 2016; accepted 20 March 2017

\begin{abstract}
The concept of Tabula Rasa, as a desire for sweeping renewal and creating a potential site for the construction of utopian dreams is presupposition of Modern Architecture. Starting from the middle of the 19th century to the first half of the 20th century, Iranian urban and architectural history has been integrated with modernization, and western-influenced modernity. The case of Tehran as the Middle Eastern political capital is the main scene for the manifestation of modernity within it's urban projects that was associated with several changes to the social, political and spatial structure of the city. In this regard, the strategy of Tabula Rasa as a utopian blank slate upon which a new Iran could be conceived "over again" - was the dominant strategy of modernization during First Pahlavi era (1925-1941). This article explores the very concept of constructing a new image of Tehran through the processes of autocratic modernism and orientalist historicism that also influenced the discourse of national identity during First Pahlavi era.
\end{abstract}

Keywords: destructive character, modern urbanism, Tabula Rasa planning, First Pahlavi era, Tehran.

\section{Introduction}

In 1931 Walter Benjamin wrote a short piece titled "het destructieve karakter: The Destructive Character". Benjamin's Denkbild (in English: Thought-image) was written in one of the worst periods in German and European history: after the crisis of 1929, when European fascism was on the rise. He states "The destructive character knows only one watchword, make room and only one activity: clearing away. It clears away the traces of our own age and has few needs, and the least of them is to know what will replace what has been destroyed. First of all, for a moment at least,

\footnotetext{
1 In Western Philosophy, the concept of Tabula Rasa can be traced back to the writings of Aristotle who writes in his treaties (De Anima, On the Soul) of the "inscribed tablet". These sources used the word "Tabula Rasa" regarding to Modern Planning of Tehran: "Shah's urban planners directed funds and attention to entirely empty stretches of the land where modernist schemes could be etched on to an arid Tabula Rasa". For more see Keshavarzian 2009: 132. Similarly, Grigor stated: "The opening of space, a modernist Tabula Rasa, for modernity to be played out was often literal, in the form of radical urban renewals in Tehran. The open space of modernity was Tehran. On this empty space, new structures with novel aesthetic traditions represented and shaped the activities and identity of bourgeoisie class" (see Grigor 2014).
}

empty space - the place where the thing stood or the victim lived. Someone is sure to be found who needs this space without occupying it" (Benjamin 1999a). Aureli (2015) argues that the theology of tabula rasa implies that we are no longer expected to do something; rather, we should make room, we should create the empty space for something else to happen.

In general perspective, the concept of Tabula Rasa had been equally a common feature of the Renaissance and the Enlightenment, both of which presented them as new develops from the root. Giedion and Zevi, linked modern architecture with the real beginnings of the architecture. Zevi investigated a modern architecture that was bound up with his commitment to a free society and free individual, out of a belief that architectural forms are closely linked to the political structure of the society (Tournikiotis 1999: 54). The strategy of Tabula Rasa appeared in the works of Rem Koolhaas and set itself as a strategy of "emptiness". Koolhaas points out a number of different cities under ambitious renovation plans starting from a large urban void implemented for various reasons. The deepest "emptiness" that inhabits the heart of the Tabula 
rasa is a void that tries to blur all specificity in order to accommodate a mere accumulation of ideologies. In a broader context, the concept of Tabula Rasa, as a desire for sweeping renewal has some precedents throughout architectural history. In the middle of nineteenth century (1853-1870), the spatial transformation of Paris by Haussmann is introduced as an archetype of modernization. New planning of Paris was commissioned to prevent any future protests, which was applied through strategic interventions that cut through the old urban fabric. Haussmann and Napoléon III found a Tabula Rasa in the newly platted avenues for new vistas. David Harvey in his book Paris, Capital of Modernity states that the Creative Destruction necessitated by the demolitions and reconstructions had its precedents in the revolutionary spirit (Harvey 2003).

Walter Benjamin in his book Arcades Project states that Haussmann's transformations had the effect of disorienting the bourgeoisie's trust in their own city. Indeed, through the observations on Paris, Benjamin discovered a connection that binds together technology, urban form, and capitalist power. Benjamin added that the urban form imposed on Paris by the reactionary Baron Haussmann after the revolution of 1848 was the appearance of a new and radical urban experience. According to Benjamin, even if these interventions were advanced to counter the threat of another revolution (which eventually occurred in 1871), these radical transformations in Paris had the effect of disorienting the bourgeoisie's trust in city (Benjamin 1999b). Haussmann's new wide boulevards provided the military control over strategic streets and opened up areas for new commercial activity symbolized by the invention of department stores which was linked to a wider restructuring, the emergence of middle class, the increasing segregation of city by the class and representation of urban space as spectacle (Low, Smith 2006: 8). Panayatis Tournikiotis, in his book The Historiography of Modern Architecture, declares that Modern Architecture presupposes a Tabula Rasa, and the systemic elimination of any elements that might denote a continuation of the classical tradition (Tournikiotis 1999: 240). Thus, Haussmannization was an attempt to put an image "in place of a city which had lost its old means of representation". What had been lost was the idea of the city as a form of Tabula Rasa, as a potential site for the construction of utopian dreams (Clark 1984).

T. J. Clarck, in his book, The Painting of Modern Life, provides another perspective on the de-politicization that followed from Haussmannization. These processes brought modernity to Paris and also provided a framework in which another order of urban life would be allowed its mere existence. Haussmann's rebuilding of Paris, writes Clark, "was spectacular in most oppressive sense of the word" (Clark 1984: 36). In 1925, the first modern lesson of Tabula Rasa planning, for which Le Corbusier far exceeded Haussmann's desire for demolitions, proposing to knock down the entire quarter of the Marais and replace it with an elevated highway, forty-story skyscraper, and vast gardens, which were not finally implemented (Ingersoll 2006). In 1950s, Chandigarh reveals the image of the city as Tabula Rasa. By employing the architect Le Corbusier and the modern style, India's first prime minister, Jawaharlal Nehru, envisioned the city as the manifestation of India's break with past and its turn to future of progress and development. Due to these factors, and especially for the time period of the 1950s to the 1990s, architectural history has posited Chandigarh as an embodiment of the state-sponsored narrative of a modernist, planned urban utopia (Kapur 2010: 52).

In 1985, Stephen Helmer in his book entitled Hitler's Berlin: The Speer plans for reshaping the central city clarifies that Hitler ordered Speer to surpass Haussmann and construct the great hall square (Grosse Platz) as the manifestation of totalitarian regime and the capital of Nazi-dominated Europe (Helmer 1985). In fact, Speer wanted to be the Haussmann to Hitler's Napoleon: "Hitler remembered everything about the Ringstrasse, and wanted the New Berlin to surpass both it and Haussmann's Paris. For years he had kept sketches he had made of the monumental buildings he planned to erect along a magnificent wide tree-planned avenues running through the center of Berlin. He regarded Haussmann as the greatest city planner in history, but hoped that I surpass him" (Wilson 1991: 98).

Aldo Rossi in his book, L'architettura della città clarifies that the premise of contemporary theory of the city should be the city as the site of political choices. Rossi's hypothesis of autonomous architecture involved searching for a rational language to investigate the legacy of the bourgeois city and realize the notion of modernity (Rossi 2011). In this regard, studying the major changes in social conditions, political atmosphere, and spatial structure of city can reveal the major influencing paradigms. The first section of this paper, "Creative Destruction" of Tehran, investigates the initial stages of modernization processes. This section focuses on the case of Tehran in mid nineteenth century as the main scene for the manifestation of duality between modern and traditional within the Middle Eastern capital's political projects. The second part, Tehran As Modernism's “Tabula Rasa” clarifies the dominant strategy of modernization and expansion of the capital city during First Pahlavi era. Subsequently, the third 
part, "Tabula Rasa" Planning: Tehran as City of Streets (1925-1941) explores the planning politics that transformed Tehran into a style similar to the Haussmann's renovation of Paris and initiated by the destruction of old city walls and the construction of long wide boulevards. The final part, Building A New Urban Identity sums up the profound interventions that effected Iran's still unborn architectural profession. This part aims to highlight the dominant approaches that affected the bourgeoisie and social class formation during this era.

\section{"Creative destruction" of Tehran}

The advent of global economy has not only changed ways of life within cities but it has immensely impacted how architecture can form and define space. Technological developments, new modes of communication and global networks have made contemporary cities endless fields of urbanization. Since the birth of Enlightenment (from $15^{\text {th }}$ century onwards) Tehranian identified five stages of modernization based on different forms of capitalism beginning with the first stage of "Commercial Capitalism" (1500-1700) associated with "...the rise of mercantile cities such as Venice, Florence, Barcelona, Paris and London”. According to Tehranian, the expansion of these cities led to the emergence of the nation state system as the second stage of modernization (1700-1870).

In the 19th century, a new imperialism emerged with the decline of the old empires, proclaiming the third stage of modernization (1870-1945). Tehranian argues that the fourth stage of modernization (1945present) begun with the rise of globalism at the end of World War II. While the conflict between the First World (the capitalist countries) and the Second World (the socialist countries) and the revolutionary parts of the Third World during the Cold War dislocated the mechanisms needed for such a global economic operation, globalism continued to grow to foster the culture of mass consumption (see Tehranian 1995: 36-40). Tehranian's five stages of modernization cohere with scholars such as Hegel, Habermas and Weber, who consider modernity as a western product at its core. However, while globalization accelerated the global hegemony of western ideas and modernization, it also led to the rise of different non-western maternities (see Hoodashtian 2002: 62-66). Nezar Alsayyad believes that in studying the relationship between west and the Middle East, three historic phases could be perceived: the colonial period, the era of independence and nation-state building, and, the most recent phase, globalization. These phases appear to have been accompanied by three respective urban forms: the hybrid, the mod- ern or pseudo-modern and the postmodern (Isenstadt, Rizvi 2008: 255-266). ${ }^{2}$ Iran similar to non-western countries and as a country that was never colonized underwent a unique modernization process, which arose from its internal pressures. Isenstadt and Rizvi stated that the Modernism in Iran began at the cusp of twentieth century amid the rise of independent nation-states in regions once ruled by the Qajars (r. 1779-1924). Over the last 150 years, Iranian urban and architectural history has been integrated with modernization, and European-inspired modernity (Abrahamian 1982). At the same time, nationalist movement in neighboring Turkey and Iran, resulting in the rise of charismatic military leaders, who threw off centuries of imperial rule and modernized to achieve the national progress (Isenstadt, Rizvi 2008: 4-5). The advent of Mustafa Kamal in Turkey (1919) and Reza Shah in Iran (1921) brought new modes of European inspired judicial and educational reforms in an effort to forget homogenous, native identities (Hobsbawn, Ranger 1992).

During the nineteenth century, the urban and architectural history of Tehran was the field of contradictions and oppositions between various definitions of the concept of modernity. The case of Tehran in mid nineteenth century is the main scene for the manifestation of this duality within the Middle Eastern political capital's projects (Mehan 2015; 2017a). The 1858 map of Tehran drawn by August Kriziz, illustrated a polygonal walled city which consisted of the urban components observable in many other Islamic Persian cities such as residential quarters, citadel, bazaar and Friday Mosque (Fig. 1). The city at that time had two main squares including Meydan-e Arg (Citadel Square) lay inside the citadel, and the Sabzeh Meydan (Herb Market) as the market place. According to Madanipour, the structure of the city was an axial spatial structure with a clear functional organization: a political authority, economic center, a religious focus, and the living places of the people (Madanipour 1998: 30). In 1868, a team headed by General Alexander Buhler, took plan of the new city in the form of a perfect octagonal, enclosed by moats and walls inspired by Vauban's ${ }^{3}$ system for the fortification of Paris and other French cities (Fig. 2). ${ }^{4}$

Curzon, British traveler and writer (1859-1925), states that the new octagonal ramparts were copied from the fortifications of Paris before the German war

\footnotetext{
2 See the chapter entitled From Modernism to Globalization by Nezar Alsayyad.

3 For more details about the works of Vauban (1633-1707) see Morris 1994: 214-218.

4 Buhler's plan depicted a clear formal copy of Vauban's - the French military engineer-model without delivering its military function (see Fisher et al. 1991; also see Gharipour, Ozlu 2015).
} 


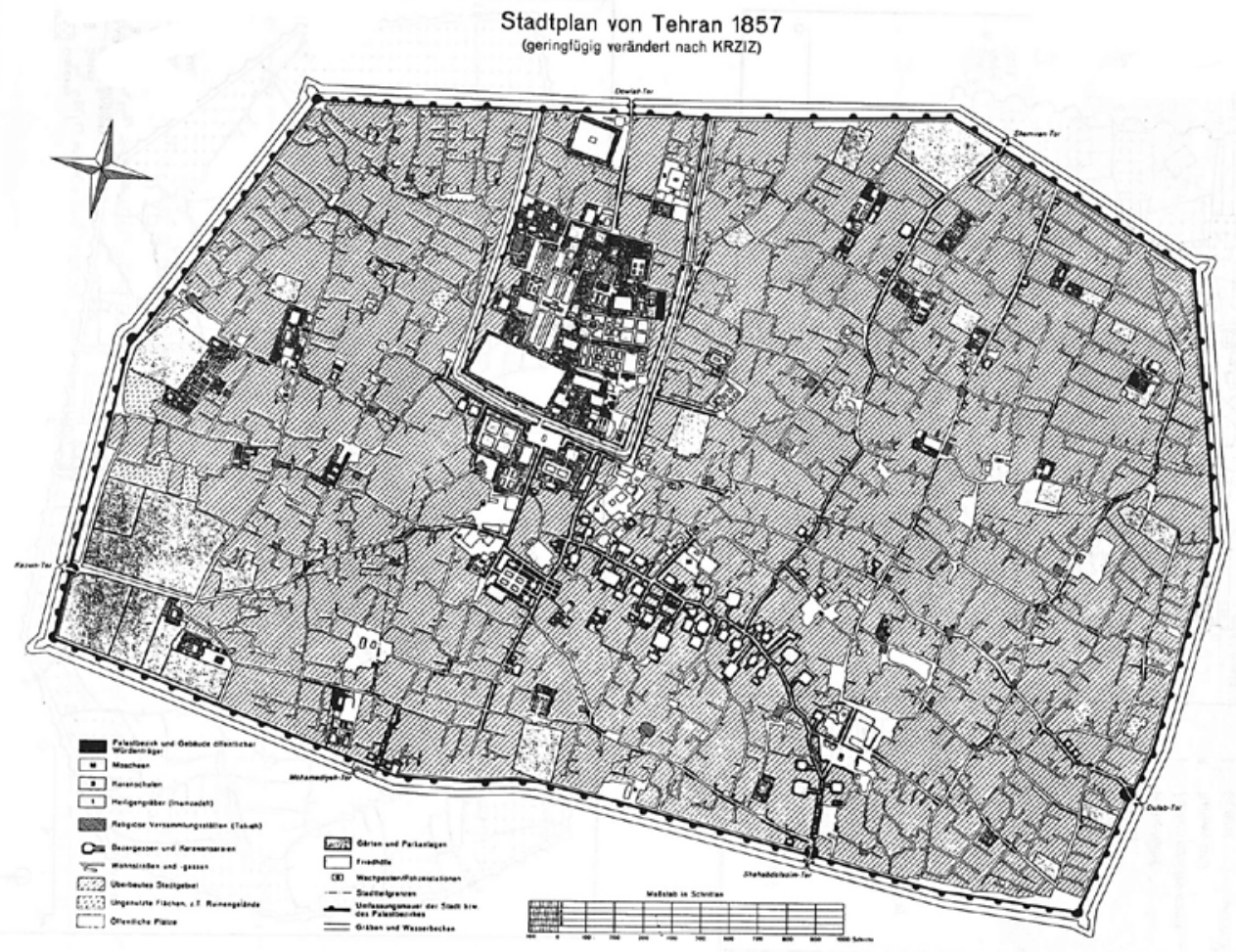

Fig. 1. Tehran Map (Russian version) 1857 by Austrian Augusta Kriziz (also Kreziz/Krsis)

Source: Reza Shirazian. The guidance for historical maps of Tehran (Tehran: Dastan, 2012), 21.

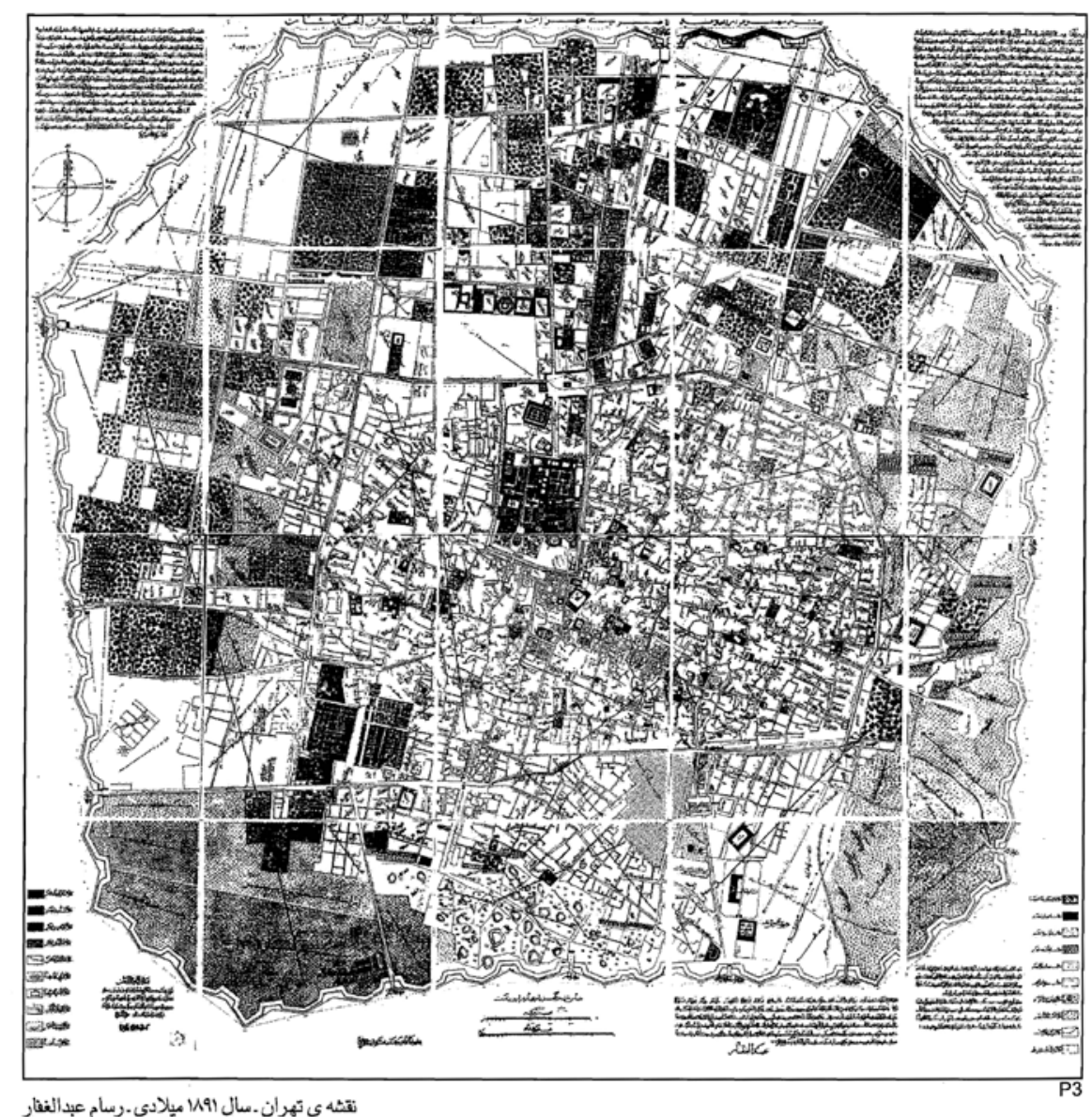

Fig. 2. Tehran Map 1891 by Abdol-Ghaffar Khan Najmol Molk

Source: Reza Shirazian. The guidance for historical maps of Tehran (Tehran: Dastan, 2012), 43. 
and had no military and defensive purpose: "The old walls and towers were for the most part pulled down, the ditch was filled up, a large slice of surrounding plain was taken in, and, at the distance of a full mile from the old enclosure, a new rampart was constructed upon Vauburn's system, copied from the fortifications of Paris before the German war. There is no masonry work upon these new fortifications; they are not defended by a single gun; they describe an octagonal figure about eleven miles in circuit; and I imagine from the point of view of the military engineers, are wholly useless for defense. The main practical service consists in facilitating the collection of the town octroi" (Curzon 1892: 305).

Although the new wall is interpreted as a purposeless copy of the French original model, a couple of reasons convinced the Naser al-Din Shah Qajar to commission new city walls, including population growth, necessity of establishing modern institutes, as well as controlling flooding (Bosworth 2007). Jackson, American Traveler and Researcher (1826-1937) added that the Naserid development of the city, where the old walls were tore down and an entirely new rampart was erected, was influenced by the Shah's first visit to Europe (Jackson 1906: 423). For Bradley-Birt, Tehran was a city, which presented "a perfect medley of things old and new, valuable and worthless without any order and management" (Bradley-Birt 1910: 300). He introduced Tehran as a "typical Eastern city", which has covered itself with "an outward western veneer". This veneer sits as strangely upon it as a new transport garment, thrown carelessly over an old and shabby "Orient" (Bradley-Birt 1910: 289). In this regard, Curzon added "we are in a city which was born and nurtured in the East, but it is beginning to cloth itself as a West-end tailor" (Curzon 1892: 304-305).

\section{Tehran as modernism's “Tabula Rasa”}

Tehran, the capital of Iran has experienced different styles of modernization during the five last decades. There were two revolutions in the last century that dramatically influenced the conditions of modernity in Tehran; the constitutional revolution (1905-1907) at the beginning of twentieth century opened the doors to modern and particularly western school of thoughts and life styles. On the other hand, Islamic Revolution (1978-1979) that challenged everything associated with the West and its modernity in the respect of the Islamic identity. ${ }^{5}$ However, since the Qajar dynasty

\footnotetext{
5 For more studies about the Tehran's Modernization processes and spatial transformations in major public squares of city, see Mehan 2017b, 2017c, 2017d.
}

(1785-1925), Tehran has been confronted with western ideological concepts (Diba 1991: 20-25).

Upon the demise of the Qajar, both Reza Shah (1925-1941) and his son, Mohammad Reza Shah (19411979), radically modernized the society that had been rooted in pre-Islamic past, Islam, and religious ideology. Such radical changes were employed in all aspects of everyday life of the society, from ideological to physical transformations (Madanipour 1998: 30). The modernization project in Tehran as the result of the global economy, similar to some other cities such as Cairo or Istanbul, was associated with several changes to the socio-spatial structure of the city (Mehan 2017d). These include deterioration of the city's historical core; emergence of wide streets, squares, parks and buildings in a semi-European style; and fast expansion of the city to accommodate migration from the provinces to the capital and formation of informal settlements, overpopulation and rise of new social classes such as bureaucrats and middle class state employees (Amirahmadi, Kiafar 1993: 109-136).

The process of Tehran Modernization started slowly during the Qajar dynasty and was more rapid and autocratic during the Pahlavi dynasty who imposed modern and western ideas and technologies both on the city form and everyday practices, to re-image the capital city and appropriate it for the world market (Mazumdar 2000: 317-338). The years between 19211934 were characterized by modernization of the bureaucratic norms. The Pahlavi state had reinforced its order by three systems: the modern army, the government bureaucracy and court patronage. Asphalt roads, the Trans-Iranian railway, new administrative buildings, secular schools and universities, modern cinemas and parks, public landmarks, and statues introduced a new lifestyle for Iranian life (Grigor 2009: 17-18). Between 1932 and 1937, the nineteenth-century ramparts and eleven gates were totally demolished. These interventions literally opened up the space for the expansion of the capital city.

Talinn Grigor, used the term "Tabula Rasa" - a utopian blank slate upon which a new Iran could be conceived "over again" - as the dominant strategy of modernization during Pahlavi era. The first symbol of this conception was the removal of old Tehran's fortifications. The rising bourgeoisie moved northward for better water, air, view, and the old aristocrats including traditionalist merchants in their bazaar, the clerics in their mosques, and the old nobility in their residential quarter remained by and gradually lost their political apparatus. In order to implement this strategy of secular formation, Tehran served as the model for modernization project around the country (Grigor 2014: 97-98). 
At the heart of the city, in order to decentralize the dense urban fabric and to bring Tehran to look like European cities, approximately 10 percent of the city was transformed into open space, including wide avenues, public squares, and city parks. The urban renewal projects in Tehran provided the utopian Tabula Rasa to build a new future for rising bourgeoisie (Grigor ibid: 100).

\section{“Tabula Rasa" planning: Tehran as city of streets (1924-1941)}

From 1924, the process of widening and constructing of Tehran streets started by announcement of municipality. ${ }^{6}$ From 1927 till 1929, Cheragh Bargh (currently Amir Kabir), Rei, Molavi, Gomrok and Istanbul Streets went through major urban interventions. ${ }^{7}$ In 1933, "Street Widening Act" passed by the parliament, provided the legal basis of urban demolition and renewal policies (Burrell 1997: 504). The Shah's demand for "rapid industrialization" led to approve "the law concerning the creation and widening of avenues and streets" (Shirazi 2015: 238). The law of the municipality by the local government of Tehran, led to the realization of the first urbanization plan with the construction of major avenues, crossing the ancient urban fabric or the line of the defensive walls which were previously unknown in the Iranian tradition. ${ }^{8}$ The new plan was designed to tear apart the historic urban fabric and making them accessible to motor vehicles (Mehan 2016b, 2016c). Takmil Homayoun described the process of widening the streets as follows: "Every day the red flags are installed and the mayor agents arrive to demolish houses" (Takmil Homayoun 2000: 49). Appointed Mayor of Tehran, Buzarjomehri, who was chosen by Reza Shah, introduced an utopian Tehran by automobiles, wide streets, electrical wagons, underground subway, plumbing water and sewage network (Safamanesh, Monadizadeh 1999: 247-273).

According to Shahri: "one of the ways in which unemployment was solved during the early years of the Pahlavi regime was the demolition of the streets

\footnotetext{
6 In this announcement it was written: "Buildings that used to be in the streets and alleys of the town were not built on the principles of architecture and engineering. Property owners should notice municipality whenever a new building constructed to be trated according to the appointed engineer at the site" (see Kiani 2000: 427).

7 Cheragh Bargh Street is situated in a historic neighborhood in Tehran-Oudlajan- surrounded by Pamenar Street, Cyrus Street (currently Mostafa Khomeini Street) and Buzarjomehri Street (currently 15 Khordad Street).

8 For constructing modern Tehran, the path of the old walls and gateways provided routes for the new wide boulevards and streets As an instance, Enqelab (Revolution) Street, which was named Shahreza at that time, was built at the place of the northern walls of the city.
}

and reconstruction of the wide avenues". He added, "almost all the economic wheels were put to motion including those directly involved in construction and the many people involved in the sale of construction material were all kept busy" (Shahri 1993). Madanipour added, "by 1932, the population density had doubled to 105 persons per hectare, and one-third of the population lived outside the walls. In addition to demographic pressure, the arrival of motor vehicles and the regime's desire to control the urban population and to modernize urban infrastructure led to a substantial transformation of the capital, in which it was radically re-planned and re-built" (Madanipour 2006).

Many areas of the capital of Tehran were transformed into a style similar to the Haussmannization of Paris, which initiated by the destruction of old city walls and the construction of long boulevards. Based on map of 1933, which is also known as "street layout plan", the spatial structure of Tehran was changed by new paved streets flanked by tree-lined sidewalks, which extended from new squares that gradually replaced old city gates (Fig. 3) (Koyagi 2015: 745-763). The new streets not only orchestrated public circulation, but also became the main routes for other infrastructure such as electricity, sewage systems and water. Additionally, they helped to free up congested areas for better accessibility in the mahallehs (residential quarters). For instance, most of Sangelaj - a neighborhood

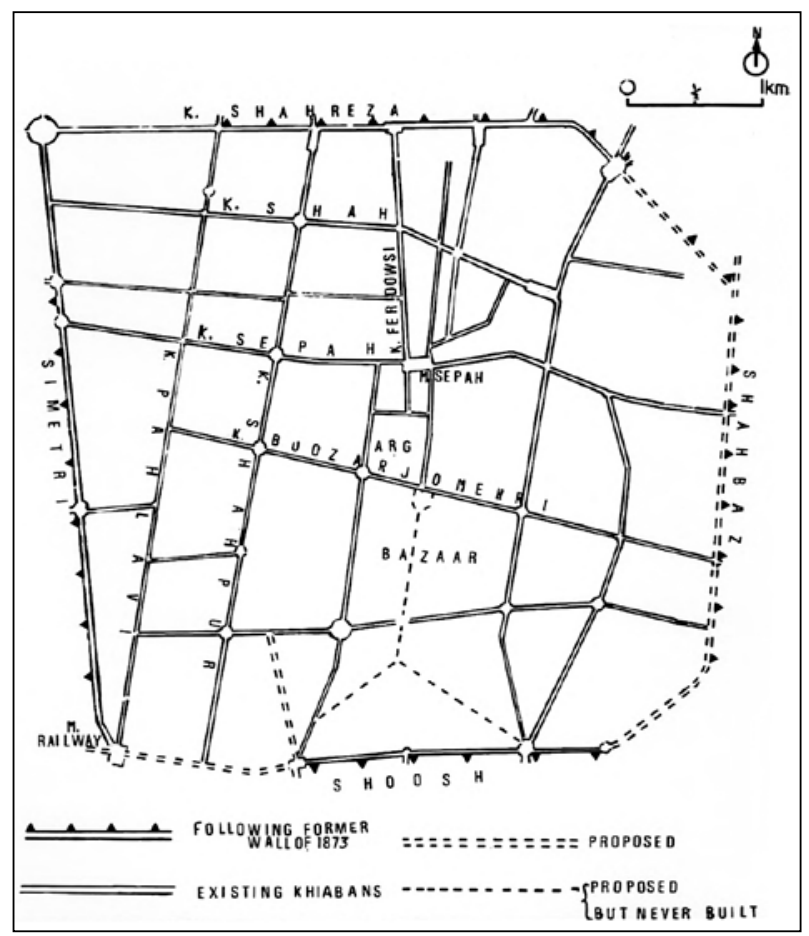

Fig. 3. The map of existing and proposed khiabans (in English: streets) of Tehran, 1937

Source: H Bahrambeygui, Tehran: An Urban Analysis, Master Thesis, Durham University, Durham E-Theses, 1972: 29-30. 
where Reza Shah had lived before taking power - was completely destroyed (Habibi et al. 2010: 85-102). ${ }^{9}$

The result of these interventions was a structurally bi-polar city with two different street layouts (Giedion 1962: 581). Charles Calmer Hart, the American diplomat to Iran, reported in 1931: “The municipality, urged on by the Shah, is trying to modernize the capital of Persia so rapidly that property owners find it almost impossible to keep up with the progress which is wiping out liberal areas of their real estate, for most of which they receive limited or no compensation. Property owners, besides having to give up much real state, have been compelled to see the demolition of their houses and to replace them at their own expense by better structures constructed on designs prescribed by municipal planning commission. ${ }^{10}$ Regarding the dimension of demolishing projects, it remarked, "Tehran looks as if it has been destroyed by an earthquake". ${ }^{11}$ Rosita Forbes, an American traveller to Iran in the early 1930s, described Tehran as "slightly Hollywoodesque, for the new streets looked as if they had not quite settled where they were going, and the rows of new houses, one room deep, were all frontage" (Forbes 1931: 105). In 1932, German archeologist and Iranologist Ernest Herzfeld, states, "Everything we see is a methodic destruction. It is a system of ruining established authorities of old, without replacing them with anything at all. The result is vacuum. One day consequences will appear". ${ }^{12}$

While the first phase of transformation included the expansion of the city and introduction of new institutions and elements into the urban fabric, the second phase involved significant intervention in and change of the physical morphology and configuration. The walls and all 12 gateways were destroyed between 1932 and 1937, to give way to a network of open spaces inspired by Haussmann's project in Paris. This final master plan approved by Reza Shah is manifested his total political authority that is a reminder of Napoleon III supremacy in the changes of Paris Master Plan (Giedion 1962: 581). In 1937 a new plan is prepared to expand the city based on the map of 1933 , which

\footnotetext{
9 Please note that the Sangelaj neighborhood was not flattened till 1950 and it was turned into a public park (see Habibi 1992).

10 US State Department Archieves, Hart, dispatch 387, 891.5123/5, 20 Febrauary 1931, Tehran, Iran qouted in M. G. Majd (2001) Great Britain and Reza Shah: The plunder of Iran, 1921-1941 (Gainesville: University of Florida Press), 162.

11 US State Department Archieves, Engert, dispatch 1830, "Change in the City of Tehran" 891.101/3, 10 May 1940, Tehran, Iran; qouted in Majd, ibid, 163-164.

12 US State Department Archieves, Engert, dispatch 1830, "Change in the City of Tehran" 891.101/3, 10 May 1940, Tehran, Iran; qouted in Majd, ibid, 163-164; US State Department Archieves, Engert, dispatch 1830, "Change in the City of Tehran" 891.101/3, 10 May 1940, Tehran, Iran; qouted in Majd, ibid, 155-156.
}

put all proposals for the new boulevards circular traffic squares and widening of old streets into one master plan, and included a series of detailed recommendations for street adjustments, dimensions and corners for easier car circulation. In this plan, streets were drawn as open-ended interventions, and gates were replaced by traffic squares to imply physical motifs of connection and expansion (Fig. 3) (Khosravi 2014).

Banani described 1930s Tehran as "a massive unfinished tableau worked on by several artists, and a mere external Westernization aimed at impressing foreign observers who usually visited only Tehran". The new city was well planned with wide streets intersecting each other at right angels, some pave with cut granite, others with asphalt or concrete. The master plan was intended to project a paradoxical contrast to the labyrinth lanes of old quarters. Banani added that the Tehran of 1941 had no resemblance to the Tehran of 1921 (Banani 1961: 144; Lockhart 1939: 11-13). Katouzian states that the dominant renewal policy was to demolish all buildings-residential, historical, monumental or whatever in order to keep them straight (Katouzian 1981: 110-111). In 1940s, American diplomats praised the city with new squares and parks in European style: "Streets have been widened and paved; trees have been planted to take the place of the old ones destroyed the alterations; modern government buildings have been erected in various parts of the city, and a number of small parks in local squares are being landscaped". ${ }^{13}$

\section{Building a new urban identity}

From 1920s to 1930s, two profound interventions effected Iran's still unborn architectural profession: first, the selective and rapid destruction of urban fabric, second, rapid revival of pre-Islamic forms predominantly Achaemenid and Sassanid Architecture. In modern Iran, Archeology positioned high culture at the heart of Politics (Fig. 4). According to Herzfeld, a historiographical strategy was developed by dividing Iran's high art into four distinct stylistic periods: "Under the Achaemenids, when Iran was center of the known world... second, the Sassanid period, which, in fact, is considered the period of Iran's progress; third, the Seljuk period when Iran became a progressive force in Islamic societies, during a time when Europe had just come out of savagery; and fourth, the Safavid period during which the Iranian craft was specially brilliant, which coincides with Europe's presentation

${ }^{13}$ US State Department Archieves, Engert, dispatch 1830, "Change
in the City of Tehran" 891.101/3, 10 May 1940, Tehran, Iran; qouted in Majd, ibid, 163-164. 


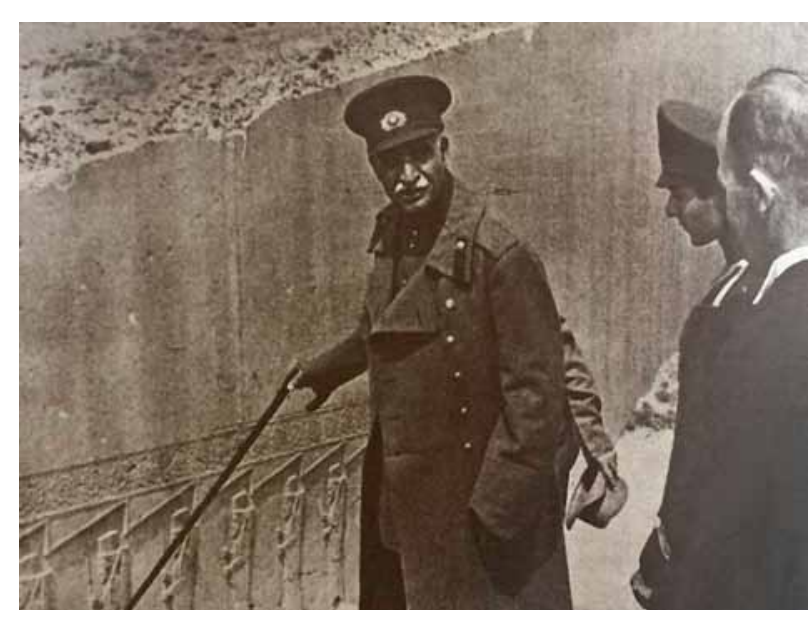

Fig. 4. Reza Shah and his son Mohammad Reza Shah at Persepolis accompanied by Ernst Herzfeld, October 1932

Source: Talinn Grigor (2009: 22).

into Asia.... no other nation has such a long heritage" (Grigor 2009: 26).

The dynamic between two invented architectural traditions- modernist and historicist- affected the politics of bourgeoisie and class formation. Therefore, avant-garde modernism and Orientalist historicism constructed the national identity during the Pahlavi era (Grigor 2013). Reza Shah's tendency to create a modern society based on nationalism and modernism values, led to create a totally new image of Tehran, in comparison to its introverted Islamic urban form till early of twentieth century. The policies of Reza Shah were based on the need to create a major change in public life and also to revolutionize the socio-political aspects of the Iranian society. In this period, the emergence of modern buildings, squares and boulevards designed by European or European-trained architects resulted in new public buildings that changed the image of Tehran. The new Ministry of Finance was erected on the site of the previous royal citadel (Fig. 5), as well, the new heading of the Justice Ministry by Gabriel Guevrekian constructed in the place of the Nayeb al-Saltaneh palace in 1936. Similarly, Ministry of Trade was constructed in the remains of royal stables. Total demolition of "Takiyeh Dolat" as the royal patronage of Shi'a rituals was highly symbolic since it was imposing structure for Shi'a rituals (Amanat 1997: 435). ${ }^{14}$

During this era, educated Europeans typically led schools of architecture. Andre Godard (1888-1965), the graduate of the Ecole des Beaux-Arts, was appointed to the post director of the first museum of an-

\footnotetext{
${ }^{14}$ Historians describe it as "the brainchild of Naser al-Din himself" and "One of the greatest edifices built under Qajar monarchy".
}

tiquities in Tehran, the Iran Bastan Museum and also the first Dean of the Faculty of Fine Arts at Tehran University is a good example. For the design of the Iran Bastan Museum Project, Godard and Maxim Siroux - French Archeologist - found inspirations for Iran's future in it's past. The monumental arch in Iran Bastan Museum was inspired by Sasanian remnants at Ctesiphon (Fig. 6). Mohsen Forughi, Iranian architect (1907-1982) studied at the Ecole des Beaux-Arts in Paris and returned to Iran to launch his architectural career. Forughi's rationalist approach to design and his use of more abstract forms adorned with a minimum of ornament, limited use of glazed tiles and wide use of reinforced concrete for his public commissions, which include hospitals, ministries and bank buildings, was different from his other colleague (Isenstadt, Rizvi 2008: 14). His vast use of concrete pointed to the iconic role of modern architecture in the nationalist ideology (Banani 1961: 144). As the result of these interventions,

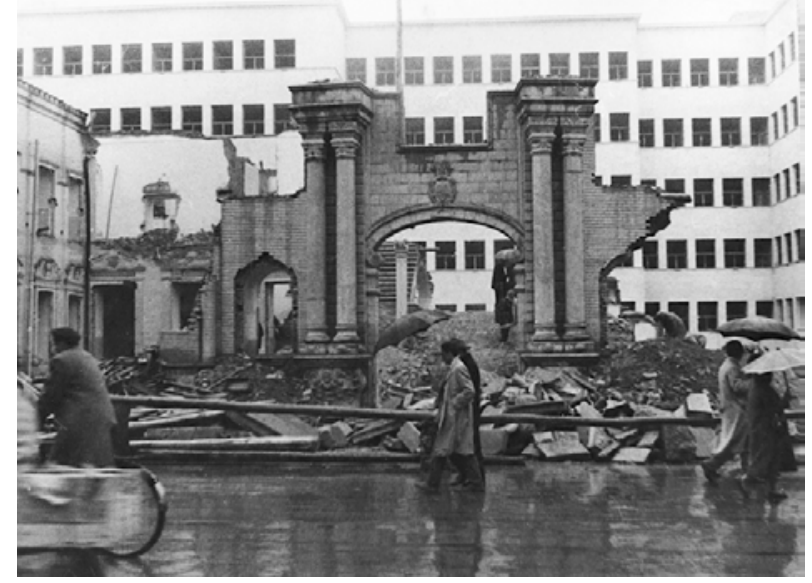

Fig. 5. Construction of the Ministry of Finance on the ruins of the Qajar Palace, Tehran

Source: Institute for Iranian Contemporary Historical Studies. Photo by Ali Khadem, 1937.

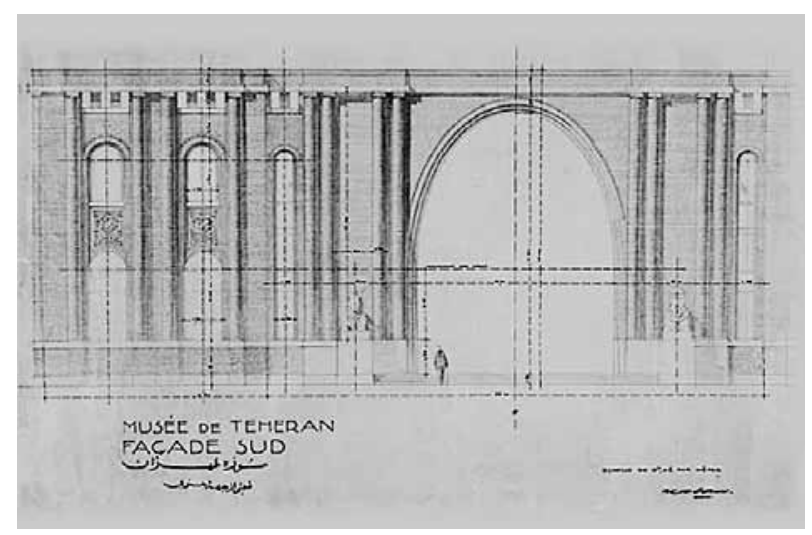

Fig. 6. National Museum of Tehran by André Godard Source: Talinn Grigor (2009: 22). 
Tehran became the field of endless modernization visualization that was going to be a pattern for other cities as well (Mehan 2016b: 547). By the end of the first Pahlavi regime in 1941, Tehran covered an area of around $46 \mathrm{~km}^{2}$, which was 2.5 times bigger than during the Qajar period (Habibi, Hourcade 2005). Ultimately; the modernity projects of the First Pahlavi were halted by the advent of Second World War and the abdication of Reza Shah.

\section{Conclusions}

During the nineteenth century, the urban and architectural history of Tehran was the field of contradictions and oppositions between various definitions of the concept of modernity. The "Creative Destruction" of Tehran initiated in mid nineteenth century as the result of western-influenced modernity. Of course, this was the consequence of much broader socio-political conditions that led to Constitutional Revolutions in 1906, as well as the establishment of Pahlavi Monarchy in 1925. Reza Shah (1925-1941) used the strategy of "Tabula Rasa" in Tehran to create a potential site for the construction of his utopian dreams.

In less than a decade, Tehran's modernization projects totally transformed its urban form, from an introverted Islamic urban fabric to an extraverted metropolis. The rise of modern architecture in Iran, under the modernist ruling ambitions of Reza Shah, led to shift dramatically from an aristocratic to bourgeois sovereignty. These interventions radically transformed the socio-political structure of the traditional city that gradually led to move the poor and working class populations from the bureaucratic centre of Tehran, while the northern parts were made comfortable for the bourgeoisie and new middle class. Reza Shah created large avenues, public squares, and public urban parks, which were meant to represent openness, modernity and democracy (Mehan 2016a: 311-321). In this era, emergence of new state architecture was the result of nationalism, historicism, secularism, and modernization values. Moreover, the return of many students that educated in western universities, introduced modern ideas, which were represented on some of the private and public buildings of this period. Reza Shah's tendency to create a modern society based on nationalism, historicism and modernism values, led to create a totally new image of Tehran. This research argues that it is only through "Tabula Rasa" planning that new national values and identities can be rebuild. The strategy of Tabula Rasa as a desire for sweeping renewal and methodic destruction that ultimately creates empty space for building new urban identity. As the result of Tabula Rasa Planning of Tehran, the city transformed into an open matrix which lead to or facilitated the production of active political space. Moreover, the strategy of Tabula Rasa transformed the city as the potential site for the construction of utopian projects during the second Pahlavi era.

\section{References}

Abrahamian, E. 1982. Iran between two reveloutions. New Jeasey: Princeton University Press.

Amanat, A. 1997. Pivot of the universe: Nasir al-Din Shah Qajar and the Iranian Monarchy, 1831-1896. London: Tauris.

Amirahmadi, H.; Kiafar, A. 1993. The transformation of Tehran from a Garrison town to a Primate city: a tale of rapid growth and uneven development in $\mathrm{H}$. Amirahmadi, S. S. El-Shakhs (Eds.). Urban development, in the Muslim world. Rutgers University Press, 109-136.

Aureli, P. V. 2015. The theology of Tabula Rasa: Walter Benjamin and architecture in the age of precarity [online], [cited 23 June 2016], The City as a Project, 9 May, 2015. Available from Internet: http://thecityasaproject.org/2015/05/thetheology-of-tabula-rasa-walter-benjamin-and-architecturein-the-age-of-precarity

Bahrambeygui, H. 1972. Tehran: an urban analysis. Durham University Press.

Banani, A. 1961. Modernization of Iran, 1921-1941. Stanford: Stanford University Press.

Benjamin, W. 1999a. The destructive character, in M. W. Jennings, H. Eiland, G. Smith (Eds.). Walter Benjamin: selected writings, Vol. 2: Part 2. Translated by Rodney Livingstone. Cambridge: The Belknap Press of Harvard University Press.

Benjamin, W. 1999b. Arcades project. Cambridge: Harvard University Press.

Bosworth, E. 2007. Historic cities of the Islamic Worlds. Netherland: Brill.

https://doi.org/10.1163/ej.9789004153882.i-616

Bradley-Birt, F. B. 1910. Through Persia, from the Gulf to the Caspian. Boston: J. B. Millet.

Burrell, R. M. 1997. Iran political diaries 1881-1965. Vol. 9. Oxford: Archieve Editions.

Clark, T. J. 1984. The painting of modern life: Paris in the art of manet and his followers. London: Thames and Hudson.

Curzon, G. 1892. Persia and Persian question. London: Longmans Green.

Diba, D. 1991. Regional report: Iran and contemporary architecture, Mimar: Architecture in Development 38: 20-25.

Fisher, W. B.; Avery, P.; Hambly, C. R. G.; Melvill. C. 1991. The Cambridge history of Iran. Cambridge: Cambridge University Press.

Forbes, R. 1931. Conflict: Angora to Afghanistan. London: Cassell.

Gharipour, M.; Ozlu, N. 2015. The city in Mulim World: depictions by Western travel writers. London and New York: Routledge.

Giedion, S. 1962. Space, time and architecture. Cambridge: Harvard University Press.

Grigor, T. 2009. Building Iran. New York: Periscope Publishing Ltd.

Grigor, T. 2014. Contemporary Iranian art: from the street to the studio. London: Reaktion Books Ltd. 
Grigor, T. 2013. The King's white walls, in B. Devos, C. Werner (Eds.). Culture and cultural politics under Reza Shah. London and New York: Routledge, 95-118.

Habibi, M. 1992. Réza Chah et le développement de Téhéran, in Ch. Adle, B. Hourcade (Eds.). Téhéran: Capitale bicentenaire. Paris and Tehran: Institut Français de Recherche en Iran, 199-206.

Habibi, M.; Hourcade, B. 2005. Atlas of Tehran metropolis: land \& people. Tehran: Urban Planning \& Processing Company, Tehran GIS Centre, Tehran Municipality.

Habibi, M.; Ahari, Z.; Emami, R. 2010. From demolishing fortifications to thoughts of highways: history of urban design in Tehran 1930-1966, Soffeh Magazine 50: 85-102.

Harvey, D. 2003. Paris: capital of modernity. London and New York: Routledge.

Helmer, S. 1985. Hitler's Berlin: the Speer plans for reshaping the central city. Brussles: UMI Research Press; First Edition edition.

Hobsbawn, E.; Ranger, T. 1992. The invention of tradition. New York: Cambridge University Press.

Hoodashtian, A. 2002. Modernite, Jahani shodan va Iran, Neveshtarhayee piramoone jahani shodan, modernite, bohrane tahavvol va nazariyeyeh adame bazgashte tarikhi dar Iran (Modernity, globalization and Iran). Tehran: Pejmen.

Ingersoll, R. 2006. Sprawltown: looking for the city on its edges. New York: Princton Architectural Press.

Isenstadt, S.; Rizvi, K. 2008. Modernism and the Middle East architecture and politics in the twenties century. University of Washington Press.

Jackson, A. W. 1906. Persia past and present. London: Macmillan.

Kapur, V. 2010. The city as Tabula Rasa versus the city as Mosaic: Chandigarh and modern Delhi, Traditional Dwellings and Settlements Review 22(1): 52-52.

Katouzian, H. 1981. The political economey of modern Iran: despotism and pseudo-modernism 1926-1979. New York: New York University Press.

https://doi.org/10.1007/978-1-349-04778-9

Keshavarzian, A. 2009. Bazaar and state in Iran: the politics of the Tehran marketplace. New York: New York University Press.

Khosravi, H. 2014. Camp of faith: on political theology and urban form: PhD Thesis, Delft University.

Kiani, M. 2000. Architecture in first Pahlavi era. Tehran: Ketab-o Farhang.

Koyagi, M. 2015. The Vernacular journey: railway travelers in Early Pahlavi Iran, 1925-50, International Journal of Middle East Studies 47: 745-763 . https://doi.org/10.1017/ S0020743815000963

Lockhart, L. 1939. Famous cities of Iranian. Brentford: W. Pearce.

Low, S.; Smith, N. 2006. The politicas of public space. London: Routledge.

Madanipour, A. 1998. Tehran: the making of a Metropolis. Willey.

Madanipour, A. 2006. Urban planning and development in Tehran, Cities 23(6): 433-438. https://doi.org/10.1016/j.cities.2006.08.002

Majd, M. G. 2001. Great Britain and Reza Shah: the plunder of Iran, 1921-1941. Gainesville: University of Florida Press.
Mazumdar, S. 2000. Autocratic control and urban design: the case of Tehran, Iran, Journal of Urban Design 5(3): 317-338. https://doi.org/10.1080/713683966

Mehan, A. 2015. Architecture for revolution: democracy and public space: presentation. Graduate Student Forum, Edinburgh College of Art, University of Edinburgh, Edinburgh: Society of Architectural Historians of Great Britain (SAHGB).

Mehan, A. 2016a. Blank Slate: squares and political order of city, Journal of Architecture and Urbanism 40(4): 311-321. https://doi.org/10.3846/20297955.2016.1246987

Mehan, A. 2016b. Public squares and their potential for social interactions: a case study of historical public squares in Tehran, World Academy of Science, Engineering and Technology, International Science Index 110, International Journal of Social, Behavioral, Educational, Economic, Business and Industrial Engineering 10(2): 544-549. scholar. waset.org/1999.10/10003692

Mehan, A. 2016c. Squares as tools for urban transformation: Foundations for designing the Iranian public squares, Revista Brasileira de Planejamento e Desenvolvimento 5(2): 246-254. https://doi.org/10.3895/rbpd.v5n2.4479

Mehan, A. 2017a. In razing its modernist buildings, Tehran is erasing its past western influence, The Conversation: 1-7.

Mehan, A. 2017b. Manifestation of modernity in Iranian public squares: Baharestan Square, International Journal of Heritage Architecture 1(3): 411-420.

https://doi.org/10.2495/HA-V1-N3-411-420

Mehan, A. 2017c. Manifestation of power: Toopkhaneh Square, Tehran, Space and Flows: An International Journal of Urban and ExtraUrban Studies 8(2): 77-88.

https://doi.org/10.18848/2154-8676/CGP/v08i02/77-88

Mehan, A. 2017d. Emerging Metropolis: politics of planning in Tehran during cold war, in Proceedings Cold War at the Crossroads: 194X-198X. Architecture and planning between politics and ideology, 13-14 June 2017, Milan, Italy.

Morris, A. E. J. 1994. History of urban form: before the industrial reveloution. 3rd ed. Essex: Pearson Education Limited.

Rossi, A. 2011. L'architettura della città. Milano: Quodlibet Abitare.

Safamanesh, K.; Monadizadeh, B. 1999. Changes in architecture and urbansim between 1920-1941, in Second Congress of Iranian Architectural History. Tehran: Cultural Heritage Organization, 247-273.

Shahri, J. 1993. The old Tehran. Vol. 1. Tehran: Moin Publishers.

Shirazian, R. 2012. The guidance for historical maps of Tehran. Vol. 1. Tehran: Dastan.

Shirazi, R. 2015. The Orient veneered in the Occident, in M. Gharipour, N. Ozlu (Eds.). The city in the Muslim world: depictions by Western travel writers. London and New York: Routledge.

Takmil Homayon, N. 2000. Cultural and social history of Tehran (in Persian). Vol. 2. Tehran: Cultural Research Center.

Tehranian, K. 1995. Modernity, space and power: the American city in discourse and practice. Hampton Press.

Tournikiotis, P. 1999. The histography of modern architecture. Cambridge: The MIT Press, 1999.

Wilson, E. 1991. The Sphinx in the city: urban life, the control of disorder, and women. Berkeley and Los Angeles, California: University of California Press. 


\section{ASMA MEHAN}

is a visiting PhD Student at EPFL (École polytechnique fédérale de Lausanne) in Lausanne (Switzerland), Former Research Fellow at the Alfred Deakin Institute (ADI) in Deakin University, Melbourne (Australia) and PhD Candidate in "ArchitectureHistory- Project" Doctoral Program in the Department of Architecture and Design (DAD), Politecnico di Torino, Torino (Italy). A graduate of Art University of Isfahan (AUI) with Master degree in Architecture and Urban Studies, she examines the relationship between democracy and the (trans)formations of urban space in Iran. Focusing on public squares, she traces their socio-political transformations as well as their role in instigating social transformations through examples that span from the pre-modern times to the present. Her current research on Tehran goes beyond the symbolic capacities of architecture and focuses on the politics of space production. Asma has been working as an Architect and Lecturer since 2010. She has ex- tensively presented her research at national and international conferences, and has received Awards, Grants and Fellowships included: Awarded Travel Grant for attending in International PhD Seminar "Comparing Habitats" supported by the "EPFL Habitat Research Center and the Laboratory of Urbanism (Lab-U, EPFL)", École Polytechnique Fédérale de Lausanne (EPFL) (Lausanne, 2017), Graduate Scholar Award by Spaces \& Flows: Seventh International Conference on Urban and ExtraUrban Studies, University of Pennsylvania (Philadelphia, 2016), 2015 Premi di Qualità (Quality Awards) by Scuola di Dottorato (Doctoral School), Politecnico di Torino (Torino, 2016), Society of Architectural Historians' (SAH) Keeper's Preservation Educational Fund Annual Conference Fellowship (Chicago-2015), and Society of Architectural Historians of Great Britain (SAHGB) Graduate Student Research Forum Travel Grant (Edinburgh 2015). 